\title{
Heterogeneous impact of agricultural support policies: evidence from Turkey
}

\author{
Alper Demirdogen ${ }^{1}$ (D) Emine Olhan ${ }^{1} \cdot$ Mehmet Hasdemir $^{2}$
}

Received: 23 July 2020 / Accepted: 28 October 2021 / Published online: 8 November 2021

(c) The Author(s), under exclusive licence to Springer Nature B.V. 2021

\begin{abstract}
Agricultural support policies, which increase production to excessive levels, have been heavily criticized for their distortional effects on farmers' decisions. High input consumption, which harms the environment, and the distribution of supports, which causes income inequality among farmers, are also the other factors that economists criticize these support policies. However, in recent years, the use and dependence on production and land have been increasing globally due to fears of food insecurity in several countries. In this article, the impact of a support policy on cotton farmers' land in Turkey is evaluated using a detailed farm-level micro dataset. We use the dynamic panel model to consider the production dynamics, unobservable individual heterogeneity, and the endogeneity of the support variable. Our results show that considering the support variable as endogenous significantly increased its impact on farmers' land. A farmer's past land allocation decisions also affected their current lands holdings. However, the results varied considerably between regions and between different land sizes. Therefore, the findings show the importance of heterogeneity in the impact of support policies. We conclude that due to the heterogeneous impact of support policies, it might not be possible to discuss the effect of support policies using an average estimate applicable for all farmers. Therefore, a different support policy considering regional characteristics or farm size is necessary to obtain the desired policy outcomes.
\end{abstract}

Keywords Support policy $\cdot$ Heterogeneous impact $\cdot$ Dynamic panel models

JEL Classification Q18 · Q12 · C23

Alper Demirdogen

demirdogen@ankara.edu.tr

Emine Olhan

emine.olhan@agri.ankara.edu.tr

Mehmet Hasdemir

mehmet.hasdemir@tarimorman.gov.tr

1 Agricultural Faculty, Department of Agricultural Economics, Ankara University, Ankara, Turkey

2 Ministry of Agriculture and Forestry, General Directorate of Plant Production, Ankara, Turkey 


\section{Introduction}

The OECD's Agricultural Policy Monitoring and Evaluation report shows that 54 countries provided more than USD 600 billion to their agriculture sectors per year from 2017 to 2019 (OECD, 2020a). Although transfers to farmers significantly declined after the mid1980 s, trends in agricultural subsidies nearly reversed after 2008. Support payments began to increase in several countries that significantly affected agriculture markets and policies. For instance, between 2008 and 2019, the share of agricultural subsidies in farmers' revenues (calculated as producer support estimates by the OECD) increased from 4.5 to $12 \%$ in China and from 8 to $12 \%$ in the USA (OECD, 2020b). Another change in agricultural support policies was in the composition of the policy tools applied. According to the OECD, the most potentially distorting transfers-e.g., market price supports, transfer based on output and input usage, budgetary transfer-notably increased in the USA. The share of these tools in total agricultural subsidies increased from 13 to 25\% between 2008 and 2019. These distorting transfers were also relatively high for other big agricultural producer countries, around $70 \%$ in China and Russia and $80 \%$ in Turkey. Therefore, the payments that significantly affect farmers' decisions-often called coupled payments-have been increasingly applied globally. Lastly, the global outbreak of the COVID-19 pandemic at the beginning of 2020 has also highlighted the importance of food security in most countries. In the coming period, it is expected that supports for farmers, especially farmers of staple crops, will also be increasingly implemented in order for farmers to main self-sufficiency.

Understanding the impact of agricultural support policies on farmers' decisions provides valuable information for policymakers in evaluating the current policies and, creating future ones, especially in discussing agricultural trade policies. One of the most popular topics in this research area is assessing the impact of agricultural support policies on production (Gardebroek et al., 2017; Goodwin \& Mishra, 2006; O’Donoghue \& Whitaker, 2010; Weber \& Key, 2012; Yu et al., 2018). The main question is whether the support policies affect farmers' production decisions along intensive and extensive margins. Discussion of these policies' impact on production is also beneficial to compare different kinds of support policy tools applied in different countries. Therefore, analyzing the impact of different support policy tools on production and eventually on trade markets becomes one of the main topics within national and international policy areas.

However, two main problems that significantly affect the impact of support policies are: endogeneity of support variables and their heterogeneous impact. As will be discussed in detail in Empirical Strategy section, the support variables might be endogenous for at least three reasons. Firstly, the support payments mostly depend on the variable on which their effect is estimated. For instance, in Turkey, the deficiency payment is made by considering farmers' land. Therefore, if one estimates the impact of support payments on farmers' land, there is a mechanical relationship; the more the land farmer owns, the more the support they will receive, and vice versa. The second problem of the support variable is selection bias. The datasets are mostly created using data from farmers who receive payments, and these farmers may also have different characteristics than those who do not receive financial support. Thirdly, farmers may have expectations for future payments, and they may change their behavior to affect future policies or in order to be eligible to obtain payments. Briefly, we have shown that the endogeneity of support policy variables is an important issue and that consideration of this problem may significantly affect the results.

Another issue in the literature on support policies is that the discussions are primarily based on an average value (e.g., the elasticity of the policy variable) and assume that 
the average impact value will be the same for all the farmers. However, farmers are not a homogenous group due to differences in region, land and financial assets, education, and personal characteristics. Therefore, the response to policies or market conditions varies among farmers. For instance, Hendricks et al. (2014) showed that the results differed significantly between the plot- and county-level estimates. They emphasized that the microlevel estimates are more likely to capture heterogeneity among farmers. Esposti (2017) showed the impact of the 2005 Common Agricultural Policy reform is heterogeneous and mostly concentrated in the lower levels of support. Koutchade et al. (2018) demonstrated that the impact of support policies would be higher than their actual value if the heterogeneity of farmers' responses was ignored. Therefore, the impact of a support policy may vary considerably between farmers and regions, even within a specific country.

This article estimated the impact of a deficiency payment policy on cotton farmers' lands in Turkey. We used a farm-level panel dataset and the dynamic panel models. Our models considered the endogeneity of land and support variables. Additionally, we presented how the heterogeneity of the impact of the support variable exists among farmers by considering different regional factors and land sizes.

In this paper, we specifically focused on the deficiency payment policy in Turkey. Due to its dependence on production and land, deficiency payments are one of the most controversial agricultural policy tools applied in Turkey. As discussed in the following sections, deficiency payment policies have been heavily criticized in the international policy arena (European Commission, 2015; OECD, 2016); however, their use and scope have increased in Turkey.

As cotton is one of the main crops featured in Turkey's deficiency payment policies, we selected cotton farmers for our empirical estimate. However, cotton is not only important in the context of agricultural policies (see OECD (2016); WTO (2017)). There are at least two other factors that increase the importance of cotton. One of them is the relationship of cotton farming with the environment. Since cotton and its support schemes can be very profitable for farmers, there are several environmental problems. Due to the intensive production of cotton and its monoculture farming, cotton-growing areas reduce the lands' organic matter over time, causing soil degradation, the clay content of the soil to increase, and the groundwater level to rise, resulting increased salinity of the soil (Bilgili et al., 2017, 2018; Çullu et al., 2009; Li et al., 2020; Reeves, 1997). Due to the salinity of cotton fields, these areas become unsuitable for any agricultural practices. Related to its water consumption, cotton consumes most of the freshwater. For instance, Turkey, Spain, and Egypt account for almost half of the total irrigated areas in the Mediterranean region. In Turkey, nearly half of the irrigation water demand comes from cotton production (Daccache et al., 2014).

The other issue with cotton is the use of child and seasonal workers in its production processes. Cotton production has played a significant role exploiting child labor, from the Manchester cotton mills in the nineteenth century to harvesting cotton in rural Egypt today (Basu, 1999; Edmonds, 2007). Even though child labor has significantly decreased globally, the cotton field continues to be the main employment area for seasonal workers and refugees (Kavak, 2016). Consequently, our crop choice has an important role in the formulation of support policies, its impact on the environment, and several social-economic factors.

As a result of this paper, we found that considering the support variable as endogenous significantly increased its impact on the land in which cotton is farmed. We also showed that farmers' previous land decisions also statistically and positively influenced farmers' current decisions. However, because of parameter heterogeneity, the impact of the support policy varies considerably among farmers. 


\section{Support policy and cotton in Turkey}

\subsection{Support policy}

At the beginning of the 2000s, Turkey's agricultural policy began to shift toward market-based policies. One of the primary sources of these changes was the Agricultural Reform Implementation Project with the World Bank (World Bank, 2009). Within the context of this project, several state-owned enterprises were privatized, and direct income supports were given. Direct income support became the primary tool in Turkey's agricultural support policy for a short time. However, in the mid-2000s, the nature of this direct income support changed, and its share in the agricultural support budget began to decrease in Turkey. As the World Bank project ended, coupled payments increased, and deficiency payments became the main tool in Turkey's agricultural policies.

The main tools implemented to support farmers in Turkey are land-based payments, agricultural insurance payments, deficiency payments, livestock payments, and environmental payments (TOB, 2017). The OECD's Producer Support Estimate was 15\% for Turkey in 2018 (OECD, 2020b). This support value was always above the OECD's average until 2018. Although the Producer Support Estimate for Turkey has decreased over time, according to national statistics, the budget for agricultural supports has almost doubled in real terms in the last fifteen years (Demirdöğen \& Olhan, 2017).

\subsection{Deficiency payment}

The reason we chose to examine deficiency payment policy is that although there are several instruments implemented to support farmers in Turkey, the deficiency payment holds a special place for farmers and policymakers, as well. Deficiency payments are awarded based on farmers' production quantity and predetermined support value. The share of deficiency payments in the total agricultural support budget was around $27 \%$ in 2020 (TOB, 2019). Deficiency payments became the primary tool used in crop payments, especially after the removal of direct income supports. Farmers apply to government agencies for deficiency payments after the harvest, submitting the invoice of their sales. The government awards farmers cash payments by multiplying their production quantity and premium levels.

The importance of deficiency payments for farmers is due to their high value. For instance, deficiency payments account for more than $95 \%$ of total support payments received by cotton farmers in Turkey (Semerci \& Çelik, 2019). Therefore, these high support payments incentivize farmers to produce cotton. However, because of their high value and coupling with production, deficiency payments create some policy problems, especially in the international arena. The European Union criticizes these tools for not being in line with its Common Agricultural Support Policy, which focuses more on decoupled payments (European Commission, 2015). The OECD also emphasizes that deficiency payments create market distortions and therefore need to be amended (OECD, 2016). However, even though Turkey's deficiency payments have garnered international criticism, their use increases over time and maintains its place in Turkey's current agricultural policy. 
A

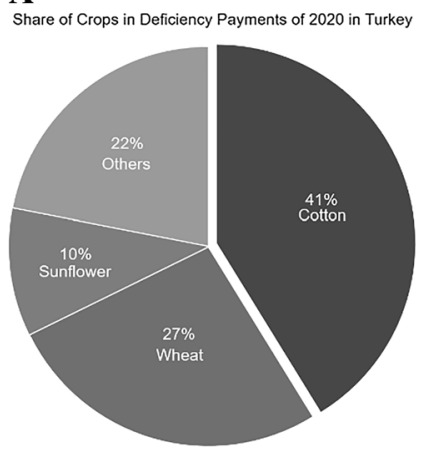

B

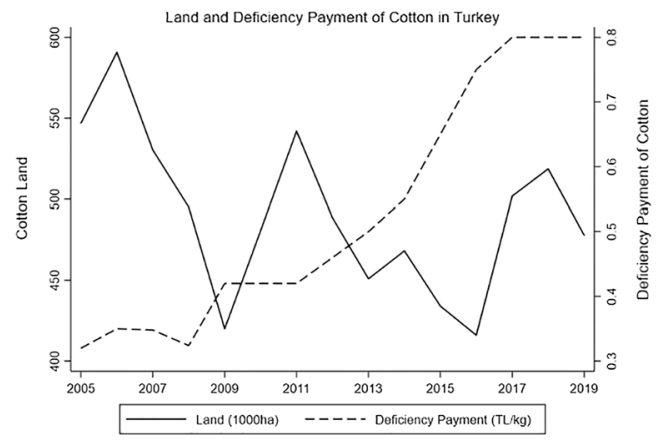

Fig. 1 Deficiency Payment of Cotton in Turkey Note Section A of this figure was estimated using the budget document of the Ministry of Agriculture and Forestry (TOB, 2019). Section B was estimated using the TurkStat database and several issues of the Official Gazette of Turkey (TurkStat, 2021)

\subsection{Cotton}

Cotton is a central part of the discussion on deficiency payments. Cotton has a special place in Turkey. Turkey holds seventh largest producer of cotton production in the world (FAOSTAT, 2021). Cotton production is an especially vital raw material for the textile industry. Textile products accounted for $17 \%$ of total exports from Turkey in 2017 (TurkStat, 2018). In order to ensure the supply of raw materials for the textile industry, there are no import duties on cotton in Turkey. Therefore, although the government supports farmers in Turkey through providing several different support policies, at the same time, the borders are open for imported cotton in order to produce more textile products in the country. Unlike other countries, because of the ban on producing genetically modified products, Turkey's cotton is also non-GMO.

The importance of cotton in Turkey's agricultural policy can be seen in the share of support payments allocated for cotton farming. As shown in Fig. 1a, cotton deficiency payments account for around $41 \%$ of total deficiency payments. The premium rates in deficiency payments for cotton also significantly increased over time (Fig. 1b). The premium rate was $0.3 \mathrm{TL} / \mathrm{kg}$ in 2005 for cotton, and it became $0.8 \mathrm{TL} / \mathrm{kg}$ in 2019. Therefore, the deficiency payments for cotton have increased by almost $160 \%$ in the last fifteen years. However, interestingly, the total land area for cotton farming has been decreasing in Turkey (Fig. 1b). For instance, the total land area used for cotton farming was 600,000 hectares in 2006, 400,000 hectares (a reduction of about 33\%) in 2016, and 500,000 hectares (an increase of $25 \%$ ) over the next two years. Because of decreasing land area, high volatility of production, and high support payments, cotton production continues to be the main topic of discussion among farmers and policymakers.

\section{Data}

Farmers must register to the Farmers' Registry System, organized by the Ministry of Agriculture and Forestry, to receive support payments in Turkey. The system provides residential information for each of farmer, such as province, district, and villages; 
Table 1 Descriptive statistics

\begin{tabular}{llcc}
\hline Variables & Definition & Mean & Std. Dev \\
\hline Cotton land (ha) & Cotton land & 8.146 & 8.836 \\
Other land (ha) & Total land minus cotton land & 6.016 & 12.40 \\
Cotton support (TL/ha) & Cotton deficiency payment per hectare & 2,454 & 358.0 \\
Plot number & Plot number normalized by cotton land & 1.016 & 5.706 \\
Cotton price (TL/kg) & Cotton prices that change by provinces & 1.544 & 0.450 \\
Fuel oil price (TL/lt) & Fuel oil prices that change by districts & 4.077 & 0.291 \\
Tenant & 1 if any amount of land is rented, 0 otherwise & 0.344 & 0.475 \\
Farmer's age & Farmer's age & 47.99 & 12.71 \\
\hline
\end{tabular}

Observation number is 86,415 . ha is hectare, TL is Turkish Lira, kg is kilogram, lt is liter

demographic information such as date of birth; and agricultural support information, such as land area, production, and support levels. Farmers register their lands and production to the system after the harvest every year to receive support payments from the government. Therefore, the registry system consists of information on production and related agricultural supports over time. In this article, we focused on cotton farmers in the Farmers' Registry System. We chose to examine two provinces (Aydin and Sanliurfa, which are at NUTS3 level) that compose $60 \%$ of Turkey's cotton lands, according to TurkStat (2021). In these two provinces, we examined the data of all cotton farmers. The period of the dataset is from 2009 to 2013. The raw dataset compiles unique panel data that consists of 144,974 observations from 47,265 individual farmers.

In addition to the Farmers' Registry System dataset, we collected price variables from other sources. The cotton price variables come from the TurkStat dataset published annually. The price variable varies between provinces (in our case, two provinces) and years. To represent farmers' production costs, we chose fuel oil prices, which have the highest share in the input cost of cotton production. For the fuel oil prices, we used data collected from the Web site of Petrol Ofisi, the largest petroleum distribution company in Turkey. The data on fuel oil prices are more detailed than the data on cotton prices. We assessed data points across three or four different days in a given month. We took the average of these days in order to determine the monthly prices, and we used the monthly producer price index $(2003=100)$ to obtain the yearly dataset. Fuel oil prices change according to the district. We converted the monetary variables (support levels, cotton, and fuel oil prices) to real terms using TurkStat's Producer Price Index $(2003=100)$.

In Turkey, farmers receive fuel oil support that is estimated based on their total land size. In our dataset, we had the fuel oil support variable. We used it to calculate farmers' total land area and then subtracted the area of land used for cotton farming from the fuel oil support variable in order to calculate the area used for other crop lands. We did not have any fuel price data for the 11th month of 2009, so we used the previous month's change rate at that data point and estimated the missing data. Within the dataset, 128 farmers did not have age data; we assigned them the average age value of the considered year. In our dataset, we excluded farmers whose cotton farming lands are less than 0.5 hectares. We also excluded farmers under the age of 18 or over 75. After this cleaning of the dataset, we had 131,311 observations left to assess. However, in order to analyze the dynamic effects of the land variable, we also excluded any farmer who did not have 
the one-year lagged cotton land variable. Consequently, 86,450 observations remained, and we provided the descriptive statistics of these observations in Table 1.

\section{Empirical strategy}

\subsection{The farmer model}

In this section, we have given a simple model of the farmer, which was constructed based on the work of Chavas and Holt (1990); Demirdogen et al. (2016); Goodwin and Mishra (2006). In this model, the farmer produces cotton as the main crop, and each farmer only receives one support policy, i.e., a deficiency payment. ${ }^{1}$

The objective function of a farmer who wants to maximize their profit is given as follows:

$$
\operatorname{Max}\{\operatorname{EU}(A * y * p-A * C\}
$$

where $E$ is the expectation operator over $p$ and $y, U$ is the utility function representing farmer's risk preferences, $A$ is the land, ${ }^{2} y$ is the yield, $p$ is the crop price, $C$ is the cost function. The model assumes that the farmer behaves based on the available information at the planting time (Chavas \& Holt, 1990). The farmer forecasts the yield and prices after the harvest.

In this article, we consider one support variable that is shown as follows:

$$
C P=A * \stackrel{\prime}{y}^{\prime} S_{c p}
$$

where $y$ is the yield level harvested or determined by the Ministry and $S_{c p}$ is the premium level of the support variable determined by the Ministry. When we add the support variable to Eq. 1, the objective function is as follows:

$$
\operatorname{Max}\{\operatorname{EU}(A * y * p-A * C+\mathrm{CP}\}
$$

\subsection{Econometric approach}

In this article, we aimed to estimate the impact of the support variable on land. Based on this aim and Eq. 3, we defined the econometric model as follows:

$$
A_{\mathrm{it}}=\beta_{0}+\beta_{1} d_{\mathrm{it}}+\beta_{2} X_{\mathrm{it}}+\varepsilon_{\mathrm{it}}
$$

\footnotetext{
${ }^{1}$ In Turkey, cotton farmers do not just receive deficiency payment. However, there are at least two reasons why we just considered one support policy. One issue is related to the data constraints. Unfortunately, we did not have enough information for other support variables. The other issue is related to the share of the output payments in total payments. Even though there are several support tools in Turkey's current agricultural policy scheme, the share of the output payments in the total supports received by the cotton farmers is more than $90 \%$.

${ }^{2}$ In our estimation, land $A$ consists of two crops. One is for cotton; one is for other crop: $A=A_{c}+A_{o}$. Here $A_{c}$ is cotton; $A_{o}$ is other crop lands. For the simplicity of the model, we did not give sub-indices of the crops.
} 
where $i$ is the farmer, $t$ is the year, $d_{i t}$ is the deficiency payment per hectare $\left(\hat{y}^{\prime} * S_{c p}\right), X_{i t}$ is the another variable, and $\varepsilon_{i t}$ is an error term distributed with mean zero and finite variance. The support variable $d_{i t}$ varies between farmers because of yield differences and premium level changes annually determined. We used that variance to estimate the impact of the policy.

The number of observations used in our dataset was larger enough to estimate the impact of the support policy. However, we did not have any variables for input usage, family labor, and off-farm income. In addition to the variables, there were several unobservable issues for us, such as the farmer's talent. To consider these issues, we added individual fixed effects $\left(\delta_{i}\right)$ in our model. We expected that adding individual fixed effects would help us to consider some unobservable issues. Our new model with the individual fixed effect is as follows:

$$
A_{\mathrm{it}}=\beta_{0}+\beta_{1} d_{\mathrm{it}}+\beta_{2} X_{\mathrm{it}}+\delta_{i}+\varepsilon_{\mathrm{it}}
$$

Farmers' current production decisions are affected by their previous production decisions (Goodwin \& Mishra, 2006; Hendricks et al., 2014). The basic assumption is that farmers are more likely to produce the same crop in the following years. However, as shown by Hendricks et al. (2014), this assumption could prove false when rotational issues (e.g., planting corn after soybeans, such as in the referenced paper) are considered. Although the relationship between crops varies between crop type and region, adding the lagged variables helps us to consider the impact of support with the lagged production relation. Therefore, we added lagged land variables to our $\operatorname{model}^{3}$ :

$$
A_{\mathrm{it}}=\beta_{0}+\beta_{1} d_{\mathrm{it}}+\beta_{2} X_{\mathrm{it}}+\beta_{3} A_{\mathrm{it}-1}+\delta_{i}+\varepsilon_{\mathrm{it}}
$$

To decrease the bias of the individual fixed effect $\left(\delta_{i}\right)$ on $\beta_{1}$, the variables could be averaged annually for a given individual, and then, the ordinary least square estimate could be used. The averaged model is given as follows:

$$
\Delta A_{\mathrm{it}}=\beta_{1} \Delta d_{\mathrm{it}}+\beta_{2} \Delta X_{\mathrm{it}}+\beta_{3} \Delta A_{\mathrm{it}-1}+\Delta \varepsilon_{\mathrm{it}}
$$

As shown in Eq. 7, the individual fixed effect $\left(\delta_{i}\right)$ was excluded from the equation, and the model could be estimated by the ordinary least square. However, because $\Delta \varepsilon_{i t}$ and $\Delta A_{i t-1}$ are both the function of $\varepsilon_{i t-1}$, we could not estimate the consistent $\beta$ parameter values (Nickell, 1981). One of the most straightforward solutions to this problem is using $\mathrm{A}_{\mathrm{it}-2}$ as an instrument for $\Delta \mathrm{A}_{\mathrm{it}-1}$ (Angrist \& Pischke, 2009). The most popular approaches that follow a similar procedure in the literature are the difference and system generalized method of moments (GMM) (Arellano \& Bond, 1991; Arellano \& Bover, 1995; Blundell \& Bond, 1998). In this article, we used the system GMM approach. System GMM estimates a system of two simultaneous equations: differences and levels equations. In the first one, lagged levels of the dependent variables are used as instruments, and in the second one, lagged differences of the dependent variables are used as instruments. One of the reasons for choosing this approach is that it outperforms the previous methods, such as Arellano and Bond (1991), when the period of the dataset is relatively short, as in our case $(t=5)$.

\footnotetext{
3 As mentioned in note 2 , in this equation too, there are two lagged land variables. One is for cotton, one is for other crop.
} 
Additionally, according to the Monte Carlo simulations in Flannery and Hankins (2013), which compare different estimation approaches, system GMM is one of the best approaches in short and unbalanced panels and for the existence of endogenous variables. Our dataset is also a short and unbalanced panel, and as explained in the following sections, we considered our support and land variables to be endogenous. Therefore, we believed that system GMM would be one of the best choices in our case.

\subsection{Postestimation tests and heterogeneity of the impact}

Two postestimation tests are used in the dynamic panel models: Arellano/Bond autocorrelation and Sargan/Hansen overidentification restriction. Arellano/Bond tests the assumption that the residuals should be independent in the second-order correlation. Sargan/ Hansen tests the validity of the instrumental variables.

In the literature, the Arellano/Bond test is required to validate the assumption of the GMM estimation and is therefore seen as a mandatory test that needs to be passed. However, the same thing cannot be said for the Sargan/Hansen test. As stated in Cameron and Trivedi (2005), rejecting the $H_{0}$ in the Sargan/Hansen test may mean two things: the endogeneity of the instrumental variables or model misspecification. However, when the dataset consists of individuals whose behaviors are heterogeneous, $H_{0}$ can be rejected even if the instrumental variables are valid (Angrist \& Pischke, 2009; Parente \& Silva, 2012; Sande $\&$ Ghosh, 2018). Because our dataset is composed of many observations and it consists of farmers who might have different responses to the support policies due to regional and land size differences, we showed that the Sargan/Hansen test might overreject even if the instrumental variables are valid. Further, the system GMM estimation is one of the best empirical approaches in the case of short panels and endogenous independent variables even if the Arellano/Bond test result is invalid (Flannery \& Hankins, 2013).

\subsection{Endogeneity of the support variable}

As seen in the following sections, the endogeneity of the support variable significantly increases its impact. There are at least three main reasons why the support variable might be endogenous: mechanical relationship, selection bias, and expectation error.

Deficiency payments in Turkey depend on farmers' land sizes, yields, and premium rates determined by the government. In this article, we estimated the impact of a support policy on land. Therefore, there is a mechanical relationship between land size and support payments: the more land the farmer has, the more support they will receive, and vice versa. As in the literature, instead of using total support payment $\left(A * y * S_{c p}\right)$, we used per hectare support level $\left(y * S_{c p}\right)$ as our independent variable. However, even in this case, there could be another relationship between yield and land size: the more land the farmer has, the more yield they may take in. Therefore, as emphasized in the study of Weber and Key (2012), the mechanical relationship between land and support policies is a possible source of the endogeneity of support variables.

As mentioned in Data section, farmers must register to the Farmers' Registry System to receive subsidies in Turkey. Therefore, we only have information for the farmers who receive support payments. We do not have any information for those who produce cotton but do not receive support payments. This is a typical example of selection bias that creates the problem of endogeneity of the support variable. Unfortunately, there are no detailed farm-level datasets for farmers who produce cotton but do not receive support payments. 
Even though farmers may choose not to apply to receive support payments, this seems unlikely considering the high level of support payments for cotton and the high costs of cotton production without support payments. Therefore, unless there are legal constraints, it can be assumed that farmers will want to receive payments and register their information into the Farmers' Registry System. However, especially concerning land ownership problems, some farmers cannot apply for support payments for the entirety or some part of their land and thus cannot receive payments for this land. Consequently, even though we think that the number of farmers who produce cotton but do not receive payments is low, there can be a sample selection bias. This problem can be coped with by considering the support variables as endogenous.

The other reason why the support variable could be endogenous is farmers' expectation errors (O’Neill \& Hanrahan, 2012). As mentioned in Farmer Model section, our model assumes that the farmer decides based on the available information at planting time and predicts yields, prices, and support payments that will be determined after the harvest. Here, especially yield and price variables contain uncertainties due to conditions such as weather and pest damage. Therefore, if there is a difference between the predicted and obtained values, an expectation error may be another source of endogeneity. ${ }^{4}$

\section{Results}

We have given our main results in Table 2, showing the impact of the support policy along with the dynamics of production, market prices, and socio-demographic variables. There are three different estimation methods: Ols (Ordinary least square), Fixed Effect, and Dynamic Panel, which is the system GMM estimate.

In our model specifications, we found that the production dynamics (lagged land variables) had a statistically significant impact on farmers' land allocation decisions. According to econometric theory, the impact of the lagged dependent variable (lagged cotton land in our case) represents the upper limit in ordinary least square estimates and the lower limit in fixed effect estimates. Therefore, we expected that the dynamic panel results would fall between these two estimates. The estimates in Table 2 were consistent with this expectation. The parameter values of lagged cotton land in dynamic panel estimates (Columns 3 and 4) are between Column 1 and Column 2 estimates. Additionally, the positive impact of the lagged variable was consistent with similar studies in the literature that were focused on different countries and crops (Jaime et al., 2016; Koutchade et al., 2018). In sum, producing cotton in the previous year positively affected the decision of current cotton production.

Other land variables were found to have a positive impact on cotton land. In fact, other land variables not only showed the relationship between cotton and other crops, but they also showed the impact of total land $\left(A=A_{c}+A_{o}\right)$. As mentioned in Goodwin and Mishra (2006), the total land variable may also be potentially endogenous. Since we examined a farm-level data set, we could consider the endogeneity of the total land variable. First, we estimated other land by subtracting the area of cotton land from total land area and considered the other and cotton land variables as endogenous variables in our estimations.

\footnotetext{
${ }^{4}$ In Column 4 Table two, in addition to the support variable, we also consider the lagged other land variable as endogenous. We do not discuss the details, because the endogeneity of the lagged other land variable has the same reasons as the lagged cotton land variable: the relationship between lagged error terms and individual fixed effects.
} 
Table 2 Parameter estimates of the cotton land model

\begin{tabular}{|c|c|c|c|c|}
\hline Variables & $\begin{array}{l}(1) \\
\text { Ols }\end{array}$ & $\begin{array}{l}(2) \\
\text { Fixed Effect }\end{array}$ & $\begin{array}{l}\text { (3) } \\
\text { Dynamic Panel }\end{array}$ & $\begin{array}{l}\text { (4) } \\
\text { Dynamic Panel with } \\
\text { Endogenous Policy } \\
\text { Variable }\end{array}$ \\
\hline Cotton land (t-1) & $\begin{array}{l}0.8055^{* * *} \\
(0.0074)\end{array}$ & $\begin{array}{l}-0.0784 * * * \\
(0.0139)\end{array}$ & $\begin{array}{l}0.4443 * * * \\
(0.0546)\end{array}$ & $\begin{array}{l}0.6101 * * * \\
(0.0293)\end{array}$ \\
\hline Other land (t-1) & $\begin{array}{l}0.0910 * * * \\
(0.0048)\end{array}$ & $\begin{array}{l}0.0558 * * * \\
(0.0072)\end{array}$ & $\begin{array}{l}0.3063^{* * * *} \\
(0.0343)\end{array}$ & $\begin{array}{l}0.5549 * * * \\
(0.0757)\end{array}$ \\
\hline Cotton support (t) & $\begin{array}{l}0.0007 * * * \\
(0.0000)\end{array}$ & $\begin{array}{l}-0.0000 \\
(0.0001)\end{array}$ & $\begin{array}{l}-0.0001 \\
(0.0001)\end{array}$ & $\begin{array}{l}0.0028 * * * \\
(0.0004)\end{array}$ \\
\hline Plot number (t) & $\begin{array}{l}-0.0274 * * * \\
(0.0068)\end{array}$ & $\begin{array}{l}-0.0308^{* *} \\
(0.0132)\end{array}$ & $\begin{array}{l}-0.0437 * * \\
(0.0198)\end{array}$ & $\begin{array}{l}-0.0391 * \\
(0.0223)\end{array}$ \\
\hline Cotton price (t-1) & $\begin{array}{l}0.2504 * * * \\
(0.0456)\end{array}$ & $\begin{array}{l}-1.8954 * * * \\
(0.3582)\end{array}$ & $\begin{array}{l}-1.1607 * * * \\
(0.2705)\end{array}$ & $\begin{array}{l}1.6724 * * * \\
(0.1344)\end{array}$ \\
\hline Fuel oil price (t-1) & $\begin{array}{l}-2.1353 * * * \\
(0.0777)\end{array}$ & $\begin{array}{l}9.3761 * * * \\
(1.3613)\end{array}$ & $\begin{array}{l}5.8975 * * * \\
(1.0098)\end{array}$ & $\begin{array}{l}-3.0170 * * * \\
(0.2142)\end{array}$ \\
\hline Tenant (t) & $\begin{array}{l}1.1700 * * * \\
(0.0428)\end{array}$ & $\begin{array}{l}3.4089 * * * \\
(0.1500)\end{array}$ & $\begin{array}{l}3.6416 * * * \\
(0.1805)\end{array}$ & $\begin{array}{l}3.5966^{* * * *} \\
(0.1812)\end{array}$ \\
\hline Farmer's age (t) & $\begin{array}{l}0.0044 * * * \\
(0.0014)\end{array}$ & $\begin{array}{l}-2.0521 * * * \\
(0.3070)\end{array}$ & $\begin{array}{l}-1.4736^{* * *} \\
(0.2236)\end{array}$ & $\begin{array}{l}0.3908^{* * * *} \\
(0.0469)\end{array}$ \\
\hline Year 2011 & $\begin{array}{l}0.5767 * * * \\
(0.0412)\end{array}$ & $\begin{array}{l}0.4900 * * * \\
(0.0586)\end{array}$ & $\begin{array}{l}0.5847 * * * \\
(0.0456)\end{array}$ & $\begin{array}{l}0.8815 * * * \\
(0.0536)\end{array}$ \\
\hline Constant & $\begin{array}{l}7.1493 * * * \\
(0.3049)\end{array}$ & $\begin{array}{l}70.4074 * * * \\
(9.7689)\end{array}$ & $\begin{array}{l}50.1300 * * * \\
(7.1299)\end{array}$ & $\begin{array}{l}-17.4346^{* * * *} \\
(2.5473)\end{array}$ \\
\hline \multicolumn{5}{|l|}{ Arellano/Bond Test } \\
\hline $\begin{array}{l}\mathrm{m} 1 \\
\mathrm{~m} 2\end{array}$ & & & $\begin{array}{l}-11.5821[0.0000] \\
3.6672[0.0002]\end{array}$ & $\begin{array}{l}-13.5728[0.0000] \\
1.8565[0.0634]\end{array}$ \\
\hline \multicolumn{5}{|l|}{ Sargan/Hansen Test } \\
\hline $\begin{array}{l}\chi^{2} \\
\text { Number of instruments }\end{array}$ & & & $\begin{array}{l}76.7970[0.0000] \\
18\end{array}$ & $\begin{array}{l}190.1440[0.0000] \\
30\end{array}$ \\
\hline Observations & 86,415 & 86,415 & 86,415 & 86,415 \\
\hline
\end{tabular}

Ols is an ordinary least square estimate, fixed effect is the fixed effect model, dynamic panel is the two-step generalized moments approach. Dynamic panel with endogenous policy variable is the two-step generalized moments approach with endogenous support policy variable. Robust standard errors were given in the parenthesis. Stars represent the significance levels: $* * * p<0.01$, ** $p<0.05, * p<0.1$. Arellano/Bond is the autocorrelation test, $\mathrm{m} 1$ is first order, $\mathrm{m} 2$ is second order, Sargan/Hansen test is the overidentification restriction, $\chi^{2}$ Chi-square. In the test section of the table, the numbers in the brackets show the $\mathrm{p}$ values

Considering endogeneity significantly increased the impact of the lagged other land variable: 0.09 in Column 1 and 0.55 in Column 4. We also thought that adding the other land variable also controlled for the heterogeneity stemming from total land differences between farmers in the dataset.

Our variable of interest was the cotton support variable (deficiency payment). We found that the impact of the cotton support variable was statistically significant in Columns 1 and 4. In the dynamic panel models, considering the endogeneity of the support variable increased its impact. For instance, in Column 3, where the endogeneity of the support policy variable 
was not considered, the parameter value of the cotton support variable is -0.0001 , and this value is not statistically significant. However, in Column 4, where we considered the endogeneity issue, the parameter value of the cotton support variable is 0.0028 , and its impact is statistically significant. This finding was also given in Yu et al. (2018). In their case, ignoring the endogeneity of the support variable significantly decreased its impact.

One problem in of Turkey's agricultural sector is fragmented land types. Farmers have too many pieces of land, and this situation reduces the efficiency of farming. To consider this problem, we estimated the impact of the plot number. This plot number variable shows the number of plots normalized by land size. We found that the plot number variable negatively affects farmers' decisions related to their land used for cotton farming.

To assess the impact of market forces, we found the expected results in two estimations (excluding Columns 2 and 3): the positive impact of the cotton price variable and the negative impact of the fuel oil price variable on farmers' lands.

One of the most popular topics in evaluating agricultural support policies has been the distribution of support payments between landowners and tenants (Allen Klaiber et al., 2017; Kirwan \& Roberts, 2016). Even though we did not focus on this topic in this article, we thought that ownership issues might have an impact on farmers' land allocation decisions. In Table 2, the tenant variable shows whether the farmer has any rented land in their cotton land. According to the results, tenancy positively and statistically affects cotton lands.

In Table 2, we controlled for the year 2011. There were two reasons for including the year dummy in our model specifications. In Roodman (2009), the addition of year dummies helped to validate the assumption of dynamic panel methods. Another reason was related to world cotton markets. In 2011, cotton prices increased by more than $50 \%$ around the world and Turkey. After that year, the price decreased at the same level as before 2011. Therefore, 2011 was an extreme year for cotton producers, and we controlled that extremity by adding the year dummy.

We have given the results for two postestimation tests at the bottom of Table 2: the Arellano/Bond autocorrelation test and Sargan/Hansen overidentification restriction test. We found a valid result (higher than 0.05 in second-order) for the Arellano/Bond autocorrelation test in Column 4, where the support policy variable was considered to be endogenous. Our Sargan/Hansen test results were smaller than 0.05 in all model specifications in Table 2. As discussed in Sect. 4.3, the results of the Sargan/Hansen test do not show the invalidity of the instruments; however, they might show that the impact of the endogenous variables significantly varies among farmers (Angrist \& Pischke, 2009; Parente \& Silva, 2012). In Discussion section, we show how the results varied due to this heterogeneity.

\section{Discussion}

\subsection{Heterogeneity of the impact of support policies}

In the following two sections, we discuss how the impact of agricultural support policies varies among farmers in order to demonstrate the importance of heterogeneity. There are several ways to present heterogeneity as shown in the literature that evaluates the relationship between land, prices, and policies. One of them is estimating the empirical model at the regional level (Hendricks et al., 2014). Another way is to separate farmers according to their land sizes and then estimate the model for the differential land size groups (Sckokai $\&$ Moro, 2006). One of the other ways is similar to land size decomposition, which groups 
farmers according to their support levels (Jaime et al., 2016). Lastly, farmers may be grouped by their financial constraints (Yi et al., 2015). In this article, we estimated our models focusing on two different kinds of heterogeneity: (1) regional heterogeneity and (2) heterogeneity by land size. We estimated our selected model (Column 4 in Table 2) separately for different regions and different groups of farmers classified according to land size.

\subsubsection{Regional heterogeneity}

In developing countries, agriculture is seen as a social sector in addition to its economic contribution. One of the reasons it is seen as a social sector is that the agriculture sector primarily consists of family farms. In Turkey, most farmers operate family farms: their farm sizes are small, the land is segregated into small pieces, and some of the country's poorest citizens work and live in this sector. From a social perspective, not only do agricultural support policies aim to increase farmers' production or land size, but they also provide a significant amount of income to low-income families. Supporting farmers in rural areas also prevents migration from rural areas to urban locations. Additionally, agricultural support policies are used to avoid exacerbating ongoing problems in urban areas such as overcrowding, unemployment, crime, inadequate housing, and pollution by keeping farmers in rural areas and thus supporting the social side of the economy.

However, the main agricultural support tools (for instance, deficiency payments) in Turkey are given to farmers based on their production. For this reason, the regions that have higher yields receive more supports than in other regions. Therefore, policymakers face a dilemma: should they support small farmers with more social supports, or should they give more support for high yield regions in order to obtain the required production for the industry (e.g., the textile industry in the case of cotton).

Regional heterogeneity of support policies also matters in the context of the environment. As discussed in Introduction section, cotton farming causes several different environmental problems. To illustrate a simple example, since the support levels are high in cotton production, farmers plant cotton in the same fields every year. Due to the requirement to use high amounts of herbicides, pesticides, fertilizer, and especially water, soil pollution, and groundwater levels increase over time. The level of soil salinity also significantly increases in cotton fields (Çullu et al., 2009). After a certain time, the land becomes unsuitable for any agricultural practices.

The heterogeneous regional impact of agricultural support policies has been attracting more attention from scholars in literature. Hinojosa et al. (2016) showed that land abandonment is not homogeneous, and mountain areas have less frequent farm abandonment than other regions. These results highlight the importance of agricultural support policies regarding land abandonment and subsequent migration to urban areas. Regarding land abandonment, Zolin et al. (2020) found that CAP payments significantly affect land productivity in the plain and mountain areas but not in the hills. The main findings in the literature related to the heterogeneous impact of support policies are the impact of payments on land values or capitalization ratios. As shown in Salhofer and Feichtinger (2021) and Ciaian et al. (2018), the capitalization rates of support payments into the land values significantly vary between different regions. Therefore, the heterogeneity of the impact of support policies was discussed in terms of their potential to intensify the problem of income inequality and the economic unsustainability of farms (Ciaian et al., 2018; Salhofer \& Feichtinger, 2021). However, as shown in Ciliberti and Frascarelli (2018), not all support tools have the same effect on income inequality. For instance, decoupled payments may 
Fig. 2 Support and land elasticities for farmers in different regions Note Elasticities were estimated using the mean values and parameters in AppendixTable 3

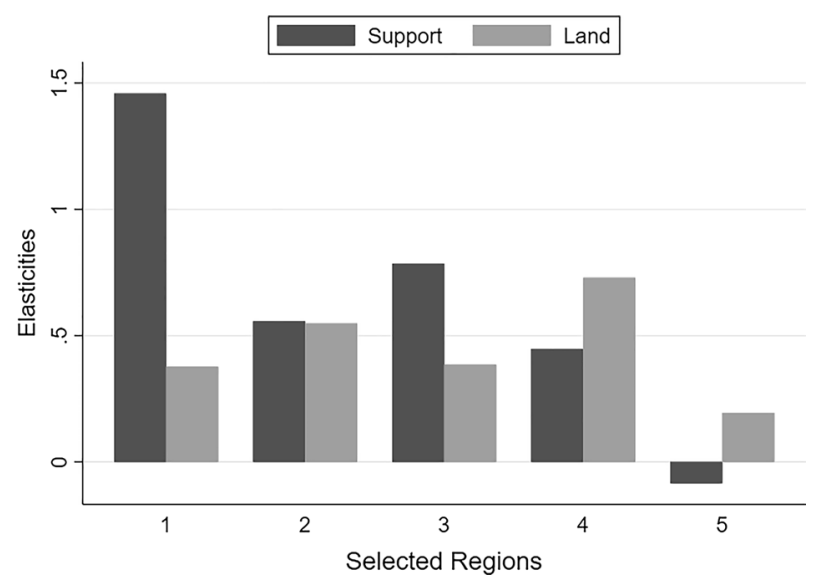

also decrease farm inequality. Consequently, the heterogeneity of the impact of support policies enriches the discussion of support policies related to their impact on land, income, or similar economic and environmental variables.

To evaluate the heterogeneous regional impact of cotton support policy in Turkey, we chose five regions. We separately estimated the dynamic panel model, which considers the support policy variable as endogenous for each region. Even though we had 28 regions in the dataset, we focused on the five biggest cotton producing regions for the sake of brevity. These five regions comprise around $70 \%$ of the total farmers in the dataset. The results are given in Appendix in Table 3. To assess the magnitude of the heterogeneity of the impact, we estimated the elasticities of cotton support and lagged cotton land variables (Fig. 2).

As shown in Appendix in Table 3 and Fig. 2, farmers' responses significantly varied among regions. The coefficient of the lagged cotton land was 0.1849 for region 5 and 0.8061 for region 4 . The impact of the support variable was only statistically significant for region 4 . Since the standard deviation of the support variable was lower in the other regions compared to region 4 , we could not find any significant impact of the support variable on land in the remaining four regions. However, the lagged land variables had statistically significant different effects, and these differences were one reason for creating heterogeneity across regions. The postestimation test results improve if we compare Appendix Table 3 results with Table 2. Four out of five regions had insignificant Arellano/Bond second-order test results as required in the dynamic panel models. However, for one region (region 4), we had a Sargan/Hansen test result greater than 0.05 . Therefore, we thought that the region was not the only source of heterogeneity, and we evaluated the land size heterogeneity in the following section.

\subsubsection{Heterogeneity by land size}

As discussed above, Turkey's main support tools are given to farmers according to their production. Since land size mainly determines production, farmers' land size becomes the main factor affecting support income received. Farmers with larger land sizes receive much more support from the government than small farmers. This issue becomes a problem primarily for family farmers operating in Turkey. Specifically, if the larger farmers continue to receive more support from the government due to their land size, land concentration and related income inequalities increase over time. Additionally, the number of small farmers 
Fig. 3 Support and land elasticities for different groups of farmers classified according to land size Note Elasticities were estimated using the mean values and parameters in AppendixTable 4

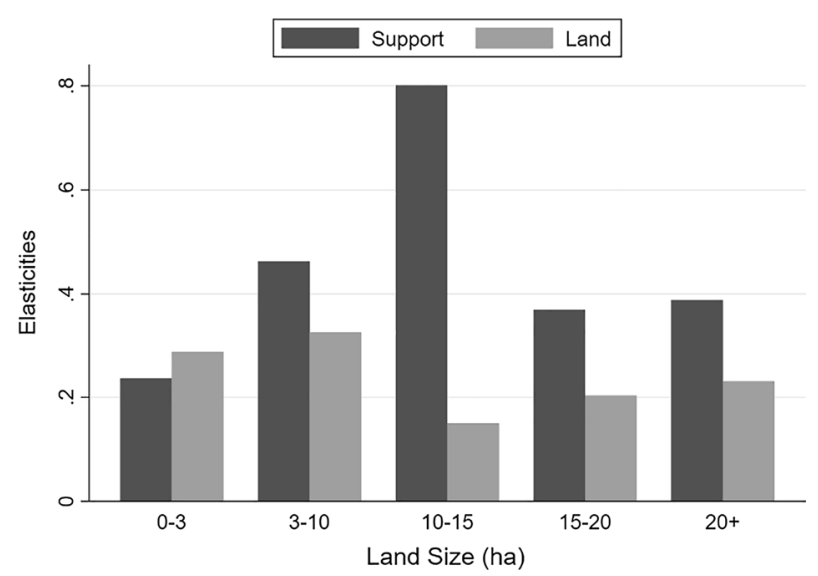

decreases and these people are forced to migrate to urban areas. Therefore, even a simple support policy tool may have the potential to create several social problems.

When discussing the heterogeneous impact of support policies, one obvious finding is that the policy's impact varies significantly across different scales of farms. For instance, as shown in Latruffe et al. (2013), farmers' response to a potential policy change substantially varies depending on farm structure, land size, and the type of farm. Biagini et al. (2020) found that policy tool efficiency is greater for large farmers than medium and small farms. They emphasized the importance of participation costs in support policies for small farms. One critical discussion on the impact of support policies is how support policies affect inequality among farmers. Zier and Petrick (2010) show that due to the increasing level of direct payments, the number of small farmers significantly decreased in Germany. In a similar vein, Roberts and Key (2008) found a strong positive association between government payments and the change in farm concentrations in the USA. However, as Piet et al. (2011) show, agricultural policies may also decrease farm size inequality if a specifically targeted policy regulating rural land management is applied. In sum, agricultural support tools have a strong relationship with the land, its size, and its distribution among farmers. Therefore, showing the heterogeneous impact of support policies considering land size can contribute to the current economic and social policy discussions.

To evaluate the heterogeneous impact of support policies considering land size, we classified farmers based on the size of their land and separately estimated our model for each group. We have given our results in Appendix in Table 4 and Fig. 3. Column 1 of Table 4. is the smallest, and Column 5 is the largest group of cotton farmers classified according to land size.

As shown in Fig. 3, farmers' lagged land elasticities are all similar. It could be said that we created more homogeneous groups because we grouped farmers according to their land size. However, in the bold bars showing the impact of the support policy, we observed a heterogeneous impact across different land sizes. The impact of cotton deficiency payments increased according to land size. However, after a specific size (around 15 ha), the impact of the policy was reduced. Therefore, the support policy had a higher impact on mediumsized land groups. In Appendix in Table 4, for two out of four groups, we obtained Arellano/Bond second-order test results greater than 0.05. We estimated Sargan/Hansen test results greater than 0.05 for none of the groups. Therefore, we concluded that land size is just one factor affecting the heterogeneous impact of support policies on farmers' behavior. In addition to differences in region or land size, farmers' experience, age, education, or similar social factors may be considered in the following papers. 


\section{Conclusion}

This article estimated the impact of a cotton support policy on land in Turkey using a detailed farm-level micro dataset. To consider the production dynamic, unobservable farmer heterogeneity, and the endogeneity of the support and land variables, we used a dynamic panel data model, namely the system GMM. We found that considering the support variable as endogenous increased its impact on the land. We also found that farmers' previous land decisions statistically and positively affected farmers' current decisions. Lastly, because of the heterogeneous impact of the support policy, the results significantly varied among farmers.

We want to emphasize two main points from our results. Firstly, as shown in our results and several papers in the literature, farmers' responses to a support policy may drastically vary depending on farmer's region, farm size, age, experience, and several other social factors. Therefore, discussing the impact of current support policies with an average policy impact that would be valid for all farmers may not be enough to show the whole picture. Positive or negative results or the magnitude of the policy's effects vary significantly between regions, production schemes, or simply different farmers' characteristics, even if we can control unobservable farmers' characteristics as in our case. These results highlight the need for regional or farm-specific policy tools. If policymakers aim to increase land size or production, it would be more optimal to give greater to the regions with higher yields. Additionally, land or farms size are also the main determinants of farmers' policy responses. Similar to regional estimates, some farmers (especially those with certain land or farm sizes) have greater land or production responses to support policies. However, if support policies are intended to be used in the context of social support providing an income for small farmers rather than as means of production distortion tools, decoupled payments would be a better choice.

Secondly and more technically, we would like to emphasize that even though postestimation tests of dynamic models are used for the validity of the models or instrumental variables, these tests may not show the validity of the results due to the heterogeneous nature of the data. When the results are robust or instrumental variables are valid, postestimation results may overreject. However, applying the Sargan/Hansen test would be quite valuable to indicate parameter heterogeneity.

Finally, we think that one of the constraints of the paper is the short period (only five years) over which the data was observed. We also only focused on one crop (cotton). Therefore, the time period could be extended, and additional crops could be evaluated. In particular, the postestimation test results could be checked against datasets that consider longer periods and observe different crops. In addition to showing the heterogeneous impact of support policies, the source of the heterogeneity could be analyzed and possibly be more useful for the policy-making process.

\section{Appendix}

See Tables 3 and 4 


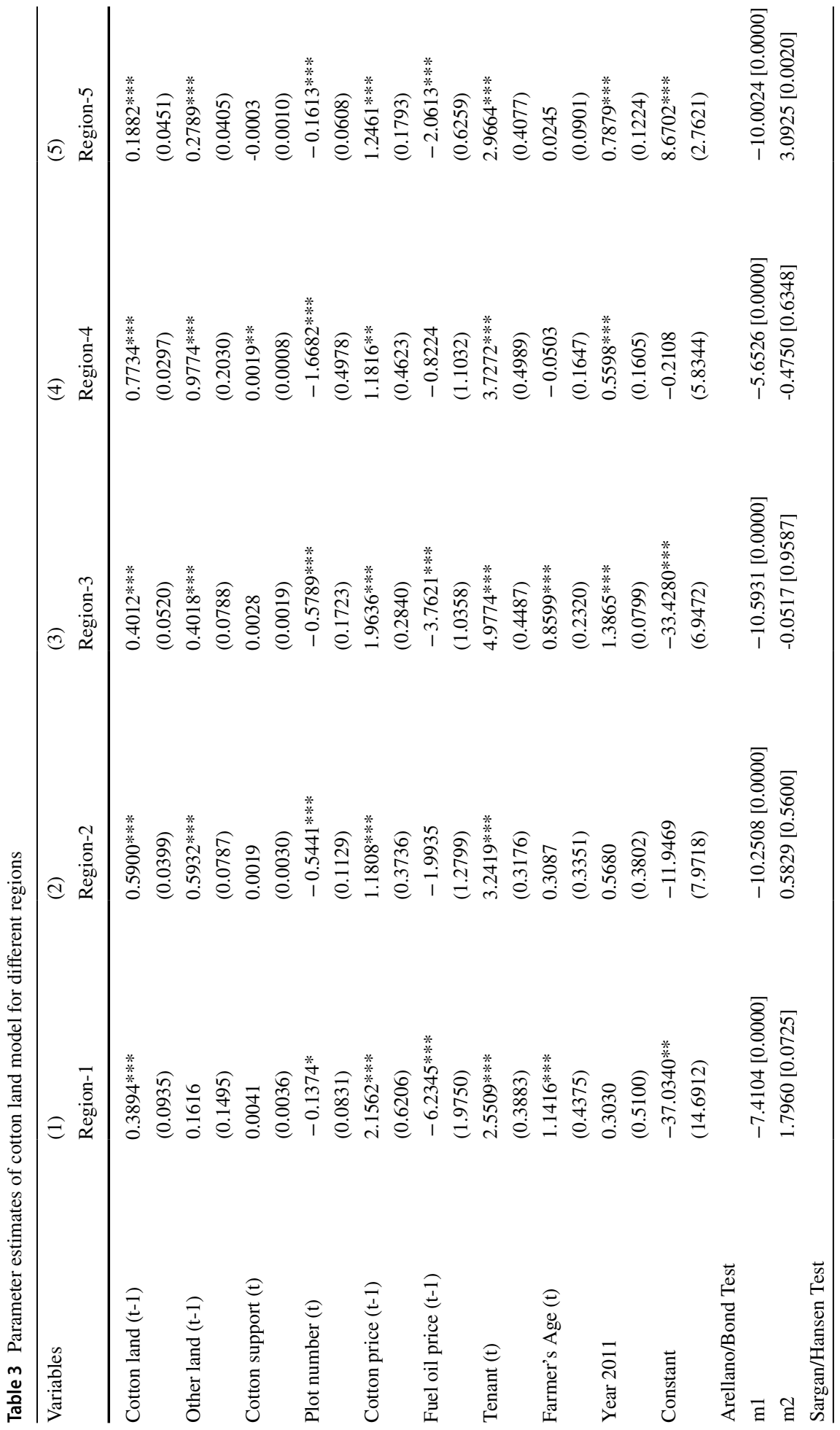




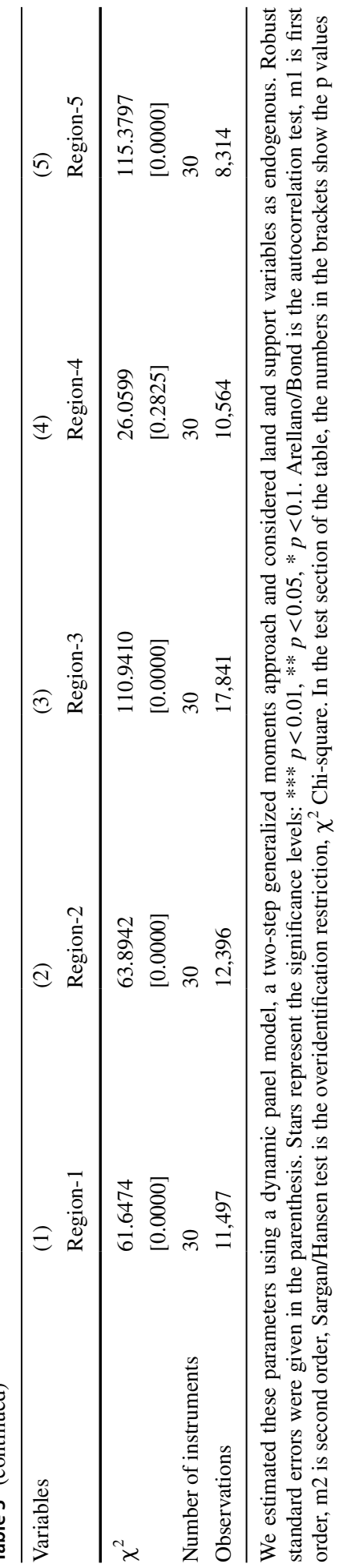




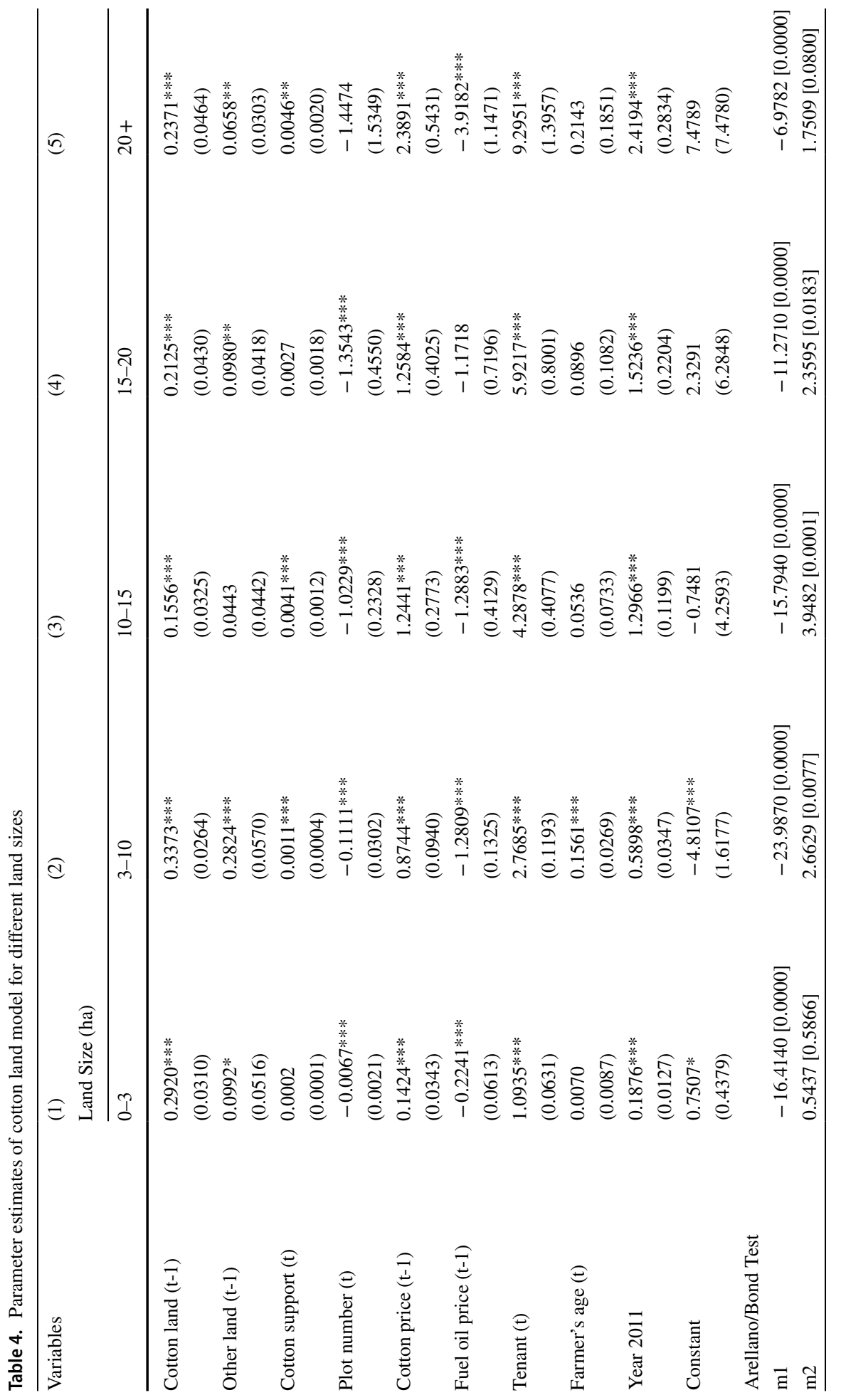




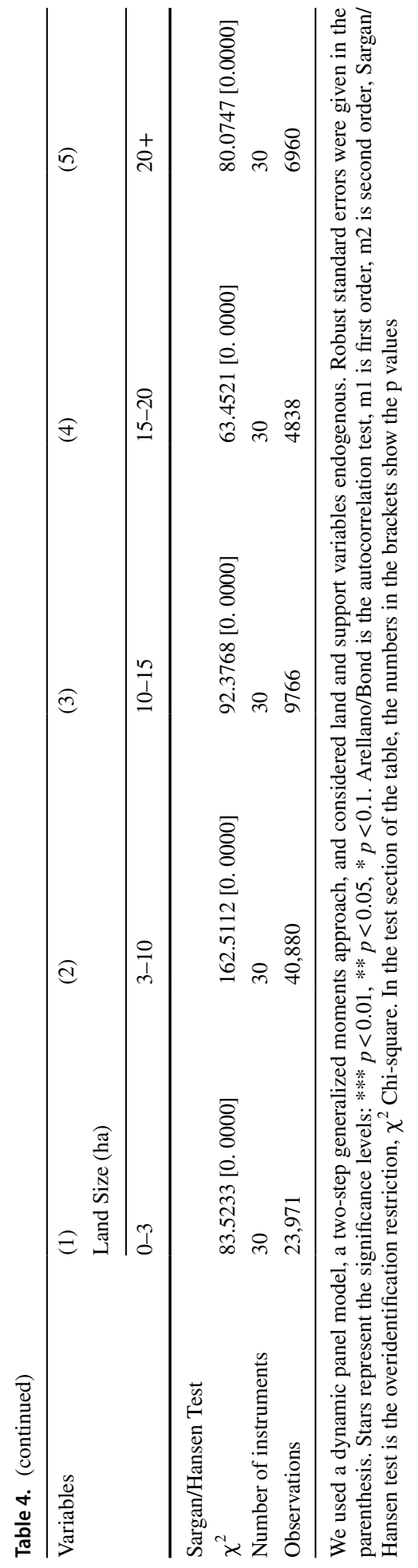


Acknowledgements The authors would like to thank Salvatore Di Falco for his valuable comments. Alper Demirdogen gratefully acknowledges financial support from TUBITAK's scholarship program of 2219.

\section{References}

Allen Klaiber, H., Salhofer, K., \& Thompson, S. R. (2017). Capitalisation of the SPS into agricultural land rental prices under harmonisation of payments. Journal of Agricultural Economics, 68(3), 710-726. https://doi.org/10.1111/1477-9552.12207

Angrist, J. D., \& Pischke, J. S. (2009). Mostly harmless econometrics: An empiricist's companion. Princeton University Press.

Arellano, M., \& Bond, S. (1991). Some tests of specification for panel data - monte-carlo evidence and an application to employment equations. Review of Economic Studies, 58(2), 277-297. https://doi.org/10. 2307/2297968

Arellano, M., \& Bover, O. (1995). Another look at the instrumental variable estimation of error-components models. Journal of Econometrics, 68(1), 29-51. https://doi.org/10.1016/0304-4076(94)01642-D

Basu, K. (1999). Child labor: Cause, consequence, and cure, with remarks on international labor standards. Journal of Economic Literature, 37(3), 1083-1119. https://doi.org/10.1257/jel.37.3.1083

Biagini, L., Antonioli, F., \& Severini, S. (2020). The role of the common agricultural policy in enhancing farm income: A dynamic panel analysis accounting for farm size in Italy. Journal of Agricultural Economics, 71(3), 652-675. https://doi.org/10.1111/1477-9552.12383

Bilgili, A. V., Kucuk, C., \& Van Es, H. M. (2017). Assessment of the quality of the Harran Plain soils under long-term cultivation. Environmental Monitoring and Assessment, 189(9), 460. https://doi.org/ 10.1007/s10661-017-6177-y

Bilgili, A. V., Yesilnacar, I., Akihiko, K., Nagano, T., Aydemir, A., Hizli, H. S., \& Bilgili, A. (2018). Postirrigation degradation of land and environmental resources in the Harran plain, southeastern Turkey. Environmental Monitoring and Assessment, 190(11), 660. https://doi.org/10.1007/s10661-018-7019-2

Blundell, R., \& Bond, S. (1998). Initial conditions and moment restrictions in dynamic panel data models. Journal of Econometrics, 87(1), 115-143. https://doi.org/10.1016/S0304-4076(98)00009-8

Cameron, A. C., \& Trivedi, P. K. (2005). Microeconometrics: Methods and applications. Cambridge University Press.

Chavas, J. P., \& Holt, M. T. (1990). Acreage Decisions under Risk - the case of corn and soybeans. American Journal of Agricultural Economics, 72(3), 529-538. https://doi.org/10.2307/1243021

Ciaian, P., Kancs, D., \& Espinosa, M. (2018). The impact of the 2013 CAP reform on the decoupled payments' capitalisation into land values. Journal of Agricultural Economics, 69(2), 306-337. https://doi. org/10.1111/1477-9552.12253

Ciliberti, S., \& Frascarelli, A. (2018). The CAP 2013 reform of direct payments: Redistributive effects and impacts on farm income concentration in Italy. Agricultural and Food Economics, 6(1), 19. https://doi. org/10.1186/s40100-018-0113-5

Daccache, A., Ciurana, J. S., Diaz, J. A. R., \& Knox, J. W. (2014). Water and energy footprint of irrigated agriculture in the Mediterranean region. Environmental Research Letters, 9(12), 124014. https://doi. org/10.1088/1748-9326/9/12/124014

Demirdogen, A., Olhan, E., \& Chavas, J. P. (2016). Food vs fiber: An analysis of agricultural support policy in Turkey. Food Policy, 61(1), 1-8. https://doi.org/10.1016/j.foodpol.2015.12.013

Demirdöğen, A., \& Olhan, E. (2017). Türkiye Tarımının Kısa Tarihi: Destekleme Politikası Özeli. Tarım Ekonomisi Dergisi.

Edmonds, E. V. (2007). Chapter 57 Child Labor. In T. P. Schultz \& J. A. Strauss (Eds.), Handbook of development economics (pp. 3607-3709). Elsevier. https://doi.org/10.1016/s1573-4471(07)04057-0

Esposti, R. (2017). The heterogeneous farm-level impact of the 2005 CAP-first pillar reform: A multivalued treatment effect estimation. Agricultural Economics, 48(3), 373-386. https://doi.org/10.1111/agec. 12340

European Commission. (2015). Turkey 2015 Report. Commision Staff Working Document.

FAOSTAT. (2021). Food and agriculture data. Retrieved 09.01. from http://www.fao.org/faostat/en/

Flannery, M. J., \& Hankins, K. W. (2013). Estimating dynamic panel models in corporate finance. Journal of Corporate Finance, 19, 1-19. https://doi.org/10.1016/j.jcorpfin.2012.09.004

Gardebroek, C., Reimer, J. J., \& Baller, L. (2017). The impact of biofuel policies on crop acreages in Germany and France. Journal of Agricultural Economics, 68(3), 839-860. https://doi.org/10.1111/14779552.12218 
Goodwin, B. K., \& Mishra, A. (2006). Are "Decoupled" farm program payments really decoupled? An empirical evaluation. American Journal of Agricultural Economics, 88(1), 73-89.

Hendricks, N. P., Smith, A., \& Sumner, D. A. (2014). Crop supply dynamics and the illusion of partial adjustment. American Journal of Agricultural Economics, 96(5), 1469-1491. https://doi.org/10.1093/ ajae/aau024

Hinojosa, L., Napoleone, C., Moulery, M., \& Lambin, E. F. (2016). The "mountain effect" in the abandonment of grasslands: Insights from the French Southern Alps. Agriculture Ecosystems \& Environment, 221, 115-124. https://doi.org/10.1016/j.agee.2016.01.032

Jaime, M. M., Coria, J., \& Liu, X. P. (2016). Interactions between CAP agricultural and agri-environmental subsidies and their effects on the uptake of organic farming. American Journal of Agricultural Economics, 98(4), 1114-1145. https://doi.org/10.1093/ajae/aaw015

Kavak, S. (2016). Syrian refugees in seasonal agricultural work: A case of adverse incorporation in Turkey. New Perspectives on Turkey, 54(54), 33-53. https://doi.org/10.1017/npt.2016.7

Kirwan, B. E., \& Roberts, M. J. (2016). Who really benefits from agricultural subsidies? Evidence from field-level data. American Journal of Agricultural Economics, 98(4), 1095-1113. https://doi.org/10. 1093/ajae/aaw022

Koutchade, O. P., Carpentier, A., \& Femenia, F. (2018). Modeling heterogeneous farm responses to European union biofuel support with a random parameter multicrop model. American Journal of Agricultural Economics, 100(2), 434-455. https://doi.org/10.1093/ajae/aax091

Latruffe, L., Dupuy, A., \& Desjeux, Y. (2013). What would farmers' strategies be in a no-CAP situation? An illustration from two regions in France. Journal of Rural Studies, 32(1), 10-25. https://doi.org/10. 1016/j.jrurstud.2013.04.003

Li, J. B., Liu, G. M., Kwak, J. Y. O., Chang, S. X., Gao, H. C., Wu, Q. C., Yang, J. S., \& Chen, J. L. (2020). Reclamation of desert land to continuous cotton cropping affects soil properties and microbial communities in the desert-oasis ecotone of Xinjiang. China. Journal of Soils and Sediments, 20(2), 862-873. https://doi.org/10.1007/s11368-019-02469-2

Nickell, S. (1981). Biases in dynamic-models with fixed effects. Econometrica, 49(6), 1417-1426. https:// doi.org/10.2307/1911408

O’Donoghue, E. J., \& Whitaker, J. B. (2010). Do direct payments distort producers' Decisions? An examination of the farm security and rural investment act of 2002. Applied Economic Perspectives and Policy, 32(1), 170-193.

O’Neill, S., \& Hanrahan, K. (2012). Decoupling of agricultural support payments: The impact on land market participation decisions. European Review of Agricultural Economics, 39(4), 639-659. https://doi. org/10.1093/erae/jbr064

OECD. (2016). Agricultural Policy Monitoring and Evaluation 2016. OECD Publishing.

OECD. (2020). Agricultural policy monitoring and evaluation. OECD publishing. https://doi.org/10.1787/ 928181a8-en

OECD. (2020b). Producer and Consumer Support Estimates database. Retrieved 15.06. from http://www. oecd.org/agriculture/agricultural-policies/producerandconsumersupportestimatesdatabase.htm

Parente, P. M. D. C., \& Silva, J. M. C. S. (2012). A cautionary note on tests of overidentifying restrictions. Economics Letters, 115(2), 314-317. https://doi.org/10.1016/j.econlet.2011.12.047

Piet, L., Latruffe, L., Le Mouel, C., \& Desjeux, Y. (2011). How do agricultural policies influence farm size inequality? The example of France. European Review of Agricultural Economics, 39(1), 5-28. https:// doi.org/10.1093/erae/jbr035

Reeves, D. W. (1997). The role of soil organic matter in maintaining soil quality in continuous cropping systems. Soil \& Tillage Research, 43(1-2), 131-167. https://doi.org/10.1016/S0167-1987(97)00038-X

Roberts, M. J., \& Key, N. (2008). Agricultural payments and land concentration: A semiparametric spatial regression analysis. American Journal of Agricultural Economics, 90(3), 627-643.

Roodman, D. (2009). A note on the theme of too many instruments. Oxford Bulletin of Economics and Statistics, 71(1), 135-158. https://doi.org/10.1111/j.1468-0084.2008.00542.x

Salhofer, K., \& Feichtinger, P. (2021). Regional differences in the capitalisation of first and second pillar payments of the CAP into land rental prices. European Review of Agricultural Economics, 48(1), 8-41. https://doi.org/10.1093/erae/jbaa028

Sande, J. B., \& Ghosh, M. (2018). Endogeneity in survey research. International Journal of Research in Marketing, 35(2), 185-204. https://doi.org/10.1016/j.ijresmar.2018.01.005

Sckokai, P., \& Moro, D. (2006). Modeling the reforms of the common agricultural policy for arable crops under uncertainty. American Journal of Agricultural Economics, 88(1), 43-56. https://doi.org/10. 1111/j.1467-8276.2006.00857.x

Semerci, A., \& Çelik, A. D. (2019). Economic analysis of cotton production in Turkey: A case study of Hatay City. Turkish Journal of Agriculture-Food Science and Technology, 7(2), 246-252. 
TOB. (2017). Tarmsal Destekler. Retrieved 28.03. from http://www.tarim.gov.tr/Konular/Tarimsal-Deste kler

TOB. (2019). 2019 Yılı Bütçe Uygulama Esasları. Tarım ve Orman Bakanlığı.

TurkStat. (2018). Foreign Trade Statistics. Retrieved 04.09. from http://www.tuik.gov.tr/PreTablo.do?alt_ $\mathrm{id}=1046$

TurkStat. (2021). Crop Production Statistics. Retrieved 09.01. from https://biruni.tuik.gov.tr/medas/?kn= $92 \&$ locale $=$ en

WTO. (2017). United States - Subsidies on Upland Cotton. Retrieved 29.03. from https://www.wto.org/ english/tratop_e/dispu_e/cases_e/ds267_e.htm

Weber, J. G., \& Key, N. (2012). How much do decoupled payments affect production? An instrumental variable approach with panel data. American Journal of Agricultural Economics, 94(1), 52-66.

World Bank. (2009). Implementation completion and results report (IBRD-46310) on a loan in the amount of US\$600 million to the Republic of Turkey for an Agricultural Reform Implementation Project. World Bank.

Yi, F. J., Sun, D. Q., \& Zhou, Y. H. (2015). Grain subsidy, liquidity constraints and food security-Impact of the grain subsidy program on the grain-sown areas in China. Food Policy, 50(1), 114-124. https://doi. org/10.1016/j.foodpol.2014.10.009

Yu, J. S., Smith, A., \& Sumner, D. A. (2018). Effects of crop insurance premium subsidies on crop acreage. American Journal of Agricultural Economics, 100(1), 91-114. https://doi.org/10.1093/ajae/aax058

Zier, P., \& Petrick, M. (2010). CAP reform and the effects of direct payments on heterogeneous farm structures in east Germany.

Zolin, M. B., Pastore, A., \& Mazzarolo, M. (2020). Common agricultural policy and sustainable management of areas with natural handicaps The Veneto Region case study. Environment Development and Sustainability, 22(8), 7587-7605. https://doi.org/10.1007/s10668-019-00537-8

Çullu, M. A., Aydemir, S., Qadir, M., Almaca, A., Ozturkmen, A. R., Bilgic, A., \& Agca, N. (2009). Implication of groundwater fluctuation on the seasonal salt dynamic in the Harran Plain south-eastern Turkey. Irrigation and Drainage, 59(4), 465-476. https://doi.org/10.1002/ird.507

Publisher's Note Springer Nature remains neutral with regard to jurisdictional claims in published maps and institutional affiliations. 